Discussion Paper No. 10-033

\title{
Market Efficiency in the Emerging Securitized Real Estate Markets
}

Felix Schindler

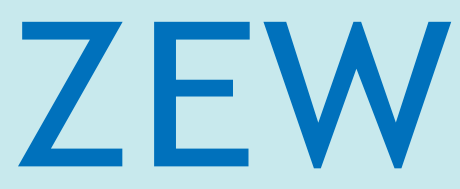

Zentrum für Europäische Wirtschaftsforschung $\mathrm{GmbH}$

Centre for European Economic Research 


\title{
Discussion Paper No. 10-033 \\ Market Efficiency in the Emerging Securitized Real Estate Markets
}

\author{
Felix Schindler
}

Download this ZEW Discussion Paper from our ftp server:

ftp://ftp.zew.de/pub/zew-docs/dp/dp10033.pdf

Die Discussion Papers dienen einer möglichst schnellen Verbreitung von neueren Forschungsarbeiten des ZEW. Die Beiträge liegen in alleiniger Verantwortung der Autoren und stellen nicht notwendigerweise die Meinung des ZEW dar.

Discussion Papers are intended to make results of ZEW research promptly available to other economists in order to encourage discussion and suggestions for revisions. The authors are solely responsible for the contents which do not necessarily represent the opinion of the ZEW. 


\section{Non-technical Summary}

Ever since the seminal papers of Fama $(1965,1970)$, the analysis of the efficient market hypothesis has been a key topic in both theoretical and empirical capital market analysis. The efficient market hypothesis seeks to answer the question of whether stock prices fully reflect all information available at a specific point in time. Weak-form tests of the efficient market hypothesis focus on the information set of historical prices or return series.

Random walk properties of equity prices influence return dynamics, and market efficiency is often considered an essential criterion in assessing the functionality of markets and the asset pricing process, which is of significant relevance for emerging markets in particular. While there is abundant empirical evidence today that developed stock markets are at least weak form efficient and investors are not able to earn excess returns compared to a buy-and-hold strategy by developing and using trading strategies, this finding is more controversial for emerging markets. Thus, the crucial question of the analysis is whether the results from stock markets also hold for securitized real estate markets - in particular against the background that the efficient market hypothesis is rejected for even several developed securitized real estate markets, as shown by Schindler et al (2009) as well as Serrano and Hoesli (2009).

Thus, this paper examines the behavior of securitized real estate returns for twelve emerging markets as well as four developed markets over the period from January 1992 to December 2009. The analysis is based on autocorrelation tests as well as both single and multiple variance ratio tests. Furthermore, non-parametric runs tests are conducted. As a further robustness check and due to their practical relevance, trading strategies based on moving averages are implemented as well.

Empirical evidence shows that the emerging securitized real estate markets can not be considered less developed, with respect to their market efficiency characteristics, than the markets in countries such as Australia, Japan, the U.K., and the U.S. By contrast, and in contrast to the broad stock markets, the price formation process at emerging markets can not be considered less efficient than that at the four mentioned developed markets from a statistical point of view. The results are confirmed by analyzing excess returns following from technical trading rules. 


\section{Das Wichtigste in Kürze}

Die Analyse der Effizienzeigenschaften von Kapitalmärkten ist spätestens seit den grundlegenden Arbeiten von Fama $(1965,1970)$ sowohl in der theoretischen als auch in der empirischen Kapitalmarktforschung ein zentraler Untersuchungsgegenstand. Die Hypothese effizienter Märkte beschäftigt sich mit der Frage, ob Wertpapierpreise alle zu einem bestimmten Zeitpunkt verfügbaren Informationen vollständig widerspiegeln. Dabei konzentriert sich die Überprüfung schwach-effizienter Märkte auf die Informationsmenge von historischen Preisen und Renditen.

Häufig wird das Kriterium der (Informations-) Effizienz auch zur Beurteilung der Leistungsfähigkeit und Funktionsfähigkeit von Märkten herangezogen. Während in der Wissenschaft heute weitgehend Einigkeit darüber besteht, dass die Aktienmärkte zumindest als schwach-informationseffizient bezeichnet werden können und es Anlegern daher nicht möglich ist, durch Handelsstrategien gegenüber einer Buy-and-Hold-Strategie Überrenditen zu erzielen, ist gerade für die Emerging Markets festzustellen, dass deren Aktienmärkte sich häufig als weniger effizient erweisen als die der entwickelten Märkte. Daher besteht die zentrale Fragestellung der Analyse darin, ob diese Eigenschaft von Emerging Markets auch auf die Immobilienaktienmärkte zutrifft - gerade vor dem Hintergrund, dass Analysen von Schindler et al. (2009) sowie von Serrano und Hoesli (2009) zeigen, dass selbst die Immobilienaktienmärkte in Ländern mit einem entwickelten Finanzmarktsystem mehrheitlich als nicht effizient zu beurteilen sind.

Dieser Aufsatz untersucht das Renditeverhalten an den Immobilienaktienmärkten von zwölf Emerging Markets und vier entwickelten Märkten über einen Zeitraum von Januar 1992 bis Dezember 2009. Neben den parametrischen und nicht-parametrischen Testverfahren zur Überprüfung der Random-Walk-Hypothese wird auf Grund ihrer praktischen Relevanz eine auf gleitenden Durchschnitten basierende Handelsstrategie implementiert.

Die empirischen Ergebnisse zeigen, dass die Immobilienaktienmärkte in den Emerging Markets hinsichtlich ihrer Effizienzeigenschaften nicht als weniger entwickelt bezeichnet werden können als die Märkte in Ländern wie Australien, Großbritannien, Japan oder den USA. Im Gegenteil und im Unterschied zu den breiten Aktienmärkten sind die Preisbildungsprozesse an den Emerging Markets aus statistischer Perspektive mehrheitlich als effizienter zu beurteilen als an den vier genannten entwickelten Märkten. 


\title{
Market Efficiency in the Emerging Securitized
}

\section{Real Estate Markets}

\author{
Felix Schindler*
}

May 2010

\begin{abstract}
This paper tests the random walk hypothesis and market efficiency for twelve emerging as well as for four developed securitized real estate markets from 1992 to 2009. Random walk properties of equity prices influence return dynamics, and market efficiency is often considered an essential criterion in the assessment of the functionality of markets and the asset pricing process, which is of significant relevance for emerging markets in particular. The analysis is based on autocorrelation tests as well as both single variance and multiple variance ratio tests. Furthermore, non-parametric runs tests are conducted. Empirical evidence shows that the efficient market hypothesis in its weak form is not rejected by any statistical test for seven of the twelve analyzed emerging securitized real estate markets. This result is surprising since all four developed securitized real estate stock markets analyzed in this study do not follow a random walk. The results are confirmed by the analysis of excess returns following from technical trading rules.
\end{abstract}

Keywords: $\quad$ Securitized real estate markets, market efficiency, random walk hypothesis, variance ratio tests, runs test, trading strategies

JEL Classifications: G12; G14; G15

\footnotetext{
* Centre for European Economic Research (ZEW), P.O. Box 1034 43, D-68034 Mannheim, Germany; Phone: +49-621-1235-378; Fax: +49-621-1235-223; E-mail: schindler@zew.de.
}

I thank Peter Westerheide for valuable comments and suggestions. 


\section{Introduction}

The efficient market hypothesis has been a key topic in financial literature for more than 30 years, and there are innumerable studies considering tests of market efficiency for stock markets, bond markets, exchange rate markets, and commodity markets. The key findings from all analyses are almost similar. In general, the hypothesis, at least of weak-form market efficiency by the seminal definition of Fama (1970), is not rejected. Even if the conducted tests reject the efficient market hypothesis for some markets and for some time periods, investors trading standardized products on exchanges are usually not able to exploit these inefficiencies by earning abnormal returns.

However, related to securitized real estate markets, particularly emerging securitized real estate markets, the number of studies on market efficiency is smaller than the number of studies on other asset classes, although it is equally relevant for investors and portfolio decision-making, since real estate is characterized by low correlation to traditional asset returns and thus provides an interesting investment to improve risk-return characteristics. Regarding emerging securitized real estate markets in particular, there is one further reason why analyzing market efficiency is of particular relevance and significant importance. Emerging markets are characterized by small-capitalized listed companies, low trading volume, limited liquidity, high bid-ask spreads, low analysts' coverage, and often persistent deficiencies in the legal and institution setting of the market. Hence, testing market efficiency in its three versions is a key topic and often proves to be crucial and essential when judging whether the respective markets and the asset pricing process are well-functioning. Due to the deficiencies mentioned above, it is often expected and empirically shown that return persistence is higher in emerging markets and that emerging stock markets are thus less efficient than matured markets such as those in the U.K. and the U.S.

A widely used test of market efficiency analyzes whether individual stocks or (securitized real estate) market indices follow a random walk. If stock prices or market indices show random walk behavior, investors will be unable to persistently earn excess returns because stocks and indices are priced at their equilibrium values. By contrast, if market indices do not follow a random walk process, the pricing of capital and risk would be predictable and investors could achieve excess returns.

Early empirical studies on market efficiency apply simple tests of autocorrelation and different types of runs tests. Later the random walk hypothesis is challenged by unit root 
tests, and more recently, variance ratio tests and multiple variance ratio tests have become the preferred methodology.

The efficient market hypothesis and its three versions according to Fama (1970) have been at the core of many empirical studies on traditional asset markets in a wide range of countries with highly developed markets, e.g. Summers (1986), Fama and French (1988), Poterba and Summers (1988), Richardson and Stock (1989), and Fama (1991). They have also been examined for less-developed markets, e.g. Errunza and Losq (1985), Barnes (1986), Laurence (1986), Butler and Malaikah (1992), Agbeyegbe (1994), Huang (1995), Urrutia (1995), Grieb and Reyes (1999), Karemera et al. (1999), Ojah and Karemera (1999), Chang and Ting (2000), Abraham et al. (2002), Ryoo and Smith (2002), Smith et al. (2002), and Lim et al. (2009) among others. The studies differ mainly in the market analyzed, the time period considered, and the methodology applied in the analysis of market efficiency.

However, with regard to real estate markets, the number of studies is much lower. Most studies on the public real estate sector exclusively deal with the U.S. market and/or focus on individual securities like Mei and Gao (1995), Seck (1996), Graff and Young (1997), Nelling and Gyourko (1998), Kuhle and Alvayay (2000), Kleiman et al. (2002), as well as Jirasakuldech and Knight (2005). Their conclusions related to the random walk behavior of the U.S. securitized real estate market differ rather frequently. These differences not only exist for differing sample periods but also for nearly similar samples. With regard to the U.K. securitized real estate market, Belaire-Franch et al. (2007) provide evidence for the rejection of the efficient market hypothesis. One of the few internationally oriented studies analyzing random walk behavior of eleven national real estate stock markets based on variance ratios is conducted by Stevenson (2002). He finds persistent return patterns of mean aversion for several markets. Serrano and Hoesli (2009) compare the predictability of securitized real estate returns and stock returns for ten markets. They conclude that securitized real estate returns are more predictable than stock returns in matured REIT markets. However, stock returns are more predictable than securitized real estate returns in some of the countries which have only recently established REIT regimes. Schindler et al. (2009) conduct a more comprehensive study by testing the efficient market hypothesis for 14 national real estate stock markets from January 1990 to December 2006. They conclude that real estate stock markets are less efficient than international stock markets, implying that empirical findings suggest that investors are likely to earn excess returns by using past information in the majority of the public real estate markets. The study conducted by Schindler et al. (2009) 
mainly focuses on matured and relatively large securitized real estate markets. However, to our knowledge, no study on testing the hypothesis of weak-form market efficiency for emerging securitized real estate markets has yet to be conducted. The following analysis concentrates exactly on this topic. The paper is a subsequent study and closely related to previous work by Schindler et al. (2009) applying the same methodology.

The main objectives of this study are (1) to examine the random walk hypothesis for stock prices in twelve emerging real estate market indices, (2) to test for market efficiency across the selected markets, and (3), for practical relevance, to derive trading strategies based on technical analysis as a further robustness check on the results from statistical tests.

The remainder of this paper is organized as follows. The next section discusses the weakform version of market efficiency (Fama, 1965 and 1970) in conjunction with the random walk hypothesis and treats the methodology of variance ratio tests and runs tests. After a data description and descriptive statistics, empirical results of the applied test procedures are presented in section 3. Section 4 tests market efficiency by comparing trading strategies based on moving averages with a simple buy-and-hold approach. Section 5 draws conclusions and provides an outlook for further research.

\section{Methodology}

In its weak form, the efficient market hypothesis proposes that price changes are unpredictable. Thus, a frequently employed test of market efficiency examines whether or not prices follow a random walk. Under the random walk hypothesis, a non-predictable random mechanism generates the behavior of price changes. In the simplest version of a random walk model, the actual index $I_{t}$ equals the previous index $I_{t-1}$ plus the realization of a random variable $\varepsilon_{\mathrm{t}}$,

$$
\mathrm{I}_{\mathrm{t}}=\mathrm{I}_{\mathrm{t}-1}+\varepsilon_{\mathrm{t}}
$$

where $I_{t}$ is the natural logarithm of the index and $\varepsilon_{t}$ is a random disturbance term at time $t$, which satisfies $E\left[\varepsilon_{t}\right]=0$ and $E\left[\varepsilon_{t} \varepsilon_{t-h}\right]=0, h \neq 0$ for all $\mathrm{t}$. If the expected index changes are given by $\mathrm{E}\left[\Delta \mathrm{I}_{\mathrm{t}}\right]=\mathrm{E}\left[\varepsilon_{\mathrm{t}}\right]=0$, the best linear estimator for index $\mathrm{I}_{\mathrm{t}}$ is the previous index value $\mathrm{I}_{\mathrm{t}-1}$. Assuming that expected index changes $\mu$ are constant over time, the random walk model expands to a random walk with drift ( $\mu=$ drift parameter)

$$
\mathrm{I}_{\mathrm{t}}=\mathrm{I}_{\mathrm{t}-1}+\mu+\varepsilon_{\mathrm{t}} \text { or } \Delta \mathrm{I}_{\mathrm{t}}=\mu+\varepsilon_{\mathrm{t}} \quad \varepsilon_{\mathrm{t}} \sim \text { i.i.d. }\left(0, \sigma^{2}\right) .
$$


The random walk implies uncorrelated residuals and hence, uncorrelated returns, $\Delta \mathrm{I}_{\mathrm{t}}$; $\varepsilon_{\mathrm{t}} \sim$ i.i.d. $\left(0, \sigma^{2}\right)$ denotes that the increments $\varepsilon_{\mathrm{t}}$ are independently and identically distributed (i.i.d.) with $\mathrm{E}\left[\varepsilon_{\mathrm{t}}\right]=0$ and $\mathrm{E}\left[\varepsilon_{\mathrm{t}}{ }^{2}\right]=\sigma_{\varepsilon}{ }^{2}$.

In general, the weak-form version of market efficiency and the random walk hypothesis are not equivalent. Nevertheless, if stock prices are found to follow a random walk process, equity markets are considered weak-form efficient (Fama, 1970). Consequently, the random walk properties of index returns are considered to be an outcome of the efficient market hypothesis.

\subsection{Variance Ratio Tests of Random Walk}

The traditional random walk tests on the basis of serial correlation and unit roots are vulnerable to errors due to autocorrelation induced by non-synchronous and infrequent trading. To resolve this shortcoming (for financial time series), Lo and MacKinlay (1988, 1989) developed tests for random walks based on variance ratio estimators.

The variance of the increments of a random walk is linearly time-dependent. Thus, if the natural logarithm of index $I_{t}$ follows a pure random walk with drift (Equation (2)), the variance of index changes should increase proportionally to the observation interval $\mathrm{q}$. Suppose a series of $\mathrm{nq}+1$ price observations $\left(\mathrm{P}_{0}, \mathrm{P}_{1}, \mathrm{P}_{2}, \ldots, \mathrm{P}_{\mathrm{nq}}\right)$ measured at uniform intervals is available. If this time series follows a random walk, the variance of the $q^{\text {th }}$ difference will correspond to $q$ times the variance of first differences. Following the models of Equations (1) and (2), the variance of the first differences, denoted as $\hat{\sigma}^{2}\left[\mathrm{I}_{t}-\mathrm{I}_{\mathrm{t}-1}\right]$ and $\hat{\sigma}^{2}\left[r_{t}\right]$ respectively, grows linearly over time so that the variance of the $\mathrm{q}^{\text {th }}$ difference is

$$
\hat{\sigma}^{2}\left[I_{t}-I_{t-q}\right]=q \cdot \hat{\sigma}^{2}\left[I_{t}-I_{t-1}\right] \quad \text { or } \quad \hat{\sigma}^{2}\left[r_{t}(q)\right]=q \cdot \hat{\sigma}^{2}\left[r_{t}\right]
$$

For the $\mathrm{q}^{\text {th }}$ lag in $\mathrm{I}_{\mathrm{t}}$, where $\mathrm{q}$ is any integer greater than one, the variance ratio $\operatorname{VR}(\mathrm{q})$ is defined as

$$
\operatorname{VR}(q) \equiv \frac{\hat{\sigma}^{2}\left[r_{t}(q)\right]}{q \cdot \hat{\sigma}^{2}\left[r_{t}\right]}=1+2 \sum_{h=1}^{q-1}\left(1-\frac{h}{q}\right) \cdot \hat{\rho}(h),
$$

where $\hat{\sigma}^{2}[\cdot]$ is an unbiased estimator of the variance. The expected value of $\operatorname{VR}(q)$ is one under the null hypothesis of a random walk for all values of $q$. While $I_{t}$ describes the logarithmic price process, $r_{t}(q)$ is a $q$ period with a continuously compounded return with 
$r_{t}(q) \equiv r_{t}+r_{t-1}+\ldots+r_{t-q+1}=I_{t}-I_{t-q} . \quad \hat{\rho}(h)$ is the estimator of the $h^{\text {th }}$ serial correlation coefficient. Alternatively, values for $\operatorname{VR}(q)$ greater than one imply mean aversion, while values smaller than one imply mean reversion. Equation (4) shows that $\operatorname{VR}(q)$ is a particularly linear combination of the first h-1 autocorrelation coefficients with linearly declining weights. If $q$ behaves as a random walk, $\operatorname{VR}(q)=1$ because $\hat{\rho}(h)=0$ for all $h \geq 1$ (Campbell et al., 1997).

Under the null hypothesis of a homoscedastic increments random walk, Lo and MacKinlay (1988) derive an asymptotic standard normal test statistic for the VR. The standard z-test statistic is

$$
Z_{2}(q)=\frac{V R(q)-1}{\sqrt{\hat{\theta}_{1}(q)}}=\frac{M_{r}(q)}{\sqrt{\hat{\theta}_{1}(q)}} \sim N(0,1)
$$

where $\hat{\theta}_{1}(q)=\frac{2(2 q-1)(q-1)}{3 q(n q)}$, and $\stackrel{a}{\sim}$ denotes that the distributional equivalence is asymptotic.

Many time series have time-varying volatilities, with returns deviating from normality. When index changes are conditionally heteroscedastic over time, there may not be a linear relation during the observation intervals. Hence, Lo and MacKinlay (1988) suggest a second test statistic $Z_{2}(q)$ with a heteroscedasticity-consistent variance estimator $\hat{\theta}_{2}(q)$ :

$$
Z_{2}(q)=\frac{V R(q)-1}{\sqrt{\hat{\theta}_{2}(q)}}=\frac{M_{r}(q)}{\sqrt{\hat{\theta}_{2}(q)}} \sim N(0,1),
$$

with $\hat{\theta}_{2}(q)=\sum_{j=1}^{q-1}\left[\frac{2(q-j)}{q}\right]^{2} \cdot \hat{\delta}(j)$ and $\hat{\delta}(j)=\frac{\sum_{t=j+1}^{n q}\left(I_{t}-I_{t-1}-\hat{\mu}\right)^{2}\left(I_{t-j}-I_{t-j-1}-\hat{\mu}\right)^{2}}{\left[\sum_{t=1}^{n q}\left(I_{t}-I_{t-1}-\hat{\mu}\right)^{2}\right]}$.

If the null hypothesis is true, the modified heteroscedasticity-consistent test statistic in Equation (6) has an asymptotic standard normal distribution (Liu and He, 1991). The $\mathrm{Z}_{2}(\mathrm{q}$ ) statistic is robust to heteroscedasticity as well as to non-normal disturbance terms, and it allows for a more efficient and powerful test than the tests of Box and Pierce (1970) or of Dickey and Fuller (1979, 1981) (Lo and MacKinlay, 1989). 
The variance ratio test of Lo and MacKinlay (1988) considers one VR for a single aggregation interval $q$ by comparing the test statistics $Z_{1}(q)$ and $Z_{2}(q)$ with the critical value of a standard normal distribution. By contrast, the random walk model requires that $\operatorname{VR}(q)=1$, and hence $\operatorname{VR}_{r}(q)=\operatorname{VR}(q)-1=0$, for all selected aggregation intervals $q$ simultaneously. Neglecting the joint nature of the hypothesis may lead to inaccurate inferences. To solve this problem, Chow and Denning (1993) suggest a multiple variance ratio (MVR) test. It is based on a multiple comparison similar to a classical joint F-test. In conjunction with a set of primary Lo and MacKinlay test statistics, $\left\{Z_{1}\left(q_{i}\right) \mid i=1, \ldots, m\right\}$ and $\left\{Z_{2}\left(q_{i}\right) \mid i=1, \ldots, m\right\}$, the random walk hypothesis is rejected if any of the estimated VRs differ significantly from one. For this test, it is only necessary to consider the maximum absolute value of the test statistics (Chow and Denning, 1993):

$$
\mathrm{Z}_{1}^{*}(\mathrm{q})=\max _{1 \leq \mathrm{i} \leq \mathrm{m}}\left|\mathrm{Z}_{1}\left(\mathrm{q}_{\mathrm{i}}\right)\right| \quad \text { and } \quad \mathrm{Z}_{2}^{*}(\mathrm{q})=\max _{1 \leq \mathrm{i} \leq \mathrm{m}}\left|\mathrm{Z}_{2}\left(\mathrm{q}_{\mathrm{i}}\right)\right|
$$

The multiple variance ratio approach controls for the size of the joint test and defines a joint confidence interval for the $\operatorname{VR}\left(\mathrm{q}_{\mathrm{i}}\right)$ estimates by applying the Studentized Maximum Modulus (SMM) distribution theory. The upper $\alpha$ point is used instead of the critical values of the standard normal distribution,

$$
\operatorname{SMM}(\alpha, m, \infty)=Z_{\alpha^{+} / 2},
$$

where $\alpha^{+}=1-(1-\alpha)^{1 / m}$.

According to Equation (8), the asymptotic SMM critical value can be calculated from the conventional standard normal distribution for a large number of observations. In essence, the Chow and Denning's test is conservative by design (i.e., the critical values are larger), but even so, it has the same, or even greater, power than the conventional unit root tests against an $\mathrm{AR}(1)$ alternative. At the same time, the MVR test is robust with respect to many forms of heteroscedasticity and non-normality of the stochastic disturbance term.

\subsection{Runs Test of Market Efficiency}

Both autocorrelation tests and VR tests are based on the assumption of a linear returngenerating process. Thus, both approaches, by definition, test for linear dependencies in the price series when challenging the random walk hypothesis and the hypothesis of weak-form market efficiency. Consequently, even if the efficient market hypothesis is not rejected by 
autocorrelation tests and VR tests, it does not necessarily imply market efficiency. Thus, it is important to apply a direct test of the weak-form version of market efficiency. The nonparametric runs test investigates the independence of successive returns and does not require normality or a linear return-generating process.

A runs test determines whether the total number of runs in the sample is consistent with the hypothesis that changes are independent. If the return series exhibit a greater tendency of change in one direction, the average run will be longer and, consequently, the number of runs will be lower than that generated by a random process. In the Bernoulli case, the total number of runs is referred to as $\mathrm{N}_{\mathrm{Runs}}$ and the total expected number of runs is given by

$$
\mathrm{E}\left[\mathrm{N}_{\text {Runs }}\right]=2 \mathrm{n} \pi(1-\pi)+\pi^{2}+(1-\pi)^{2},
$$

where $\pi=\operatorname{Pr}\left(\mathrm{r}_{\mathrm{t}}>0\right)=\Phi\left(\frac{\mu}{\sigma}\right), \mu$ is the expected index change, and $\sigma$ is the standard deviation of index changes. For large sample size $(\mathrm{N}>30)$ the sampling distribution of $\mathrm{E}\left[\mathrm{N}_{\mathrm{Runs}}\right]$ is approximately normal, and a continuity correction is produced.

When the actual number exceeds (falls below) the expected runs, a positive (negative) Zvalue is obtained. Consequently, a positive (negative) $\mathrm{Z}$-value indicates a negative (positive) serial correlation in the series of index changes.

Table 1 summarizes the conclusions of the various test approaches which are applied to test for weak-form market efficiency and return predictability of emerging securitized real estate markets.

Table 1: $\quad$ Null and Alternative Hypotheses of Weak-Form Market Efficiency Tests

\begin{tabular}{lccc}
\hline Significance Test & $\begin{array}{c}\text { Autocorrelation } \\
\text { Coefficient }\end{array}$ & Variance Ratio & Runs \\
\hline Random Walk & $\rho(h)=0$ for $h \neq 0$ & $V R(h)=1$ for $h \neq 0$ & $Z=0$ \\
Mean Aversion & $\rho(h)>0$ for $h \neq 0$ & $V R(h)>1$ for $h \neq 0$ & $Z<0$ \\
Mean Reversion & $\rho(h)<0$ for $h \neq 0$ & $V R(h)<1$ for $h \neq 0$ & $Z>0$ \\
\hline
\end{tabular}




\section{Empirical Results of Weak-Form Market Efficiency Tests}

\subsection{Data and Descriptive Statistics}

The empirical analysis in this paper is based on the monthly indices from General Property Research (GPR) between January 1992 and December 2009. Thus, the time series contains up to 216 monthly data for each market and is given by the availability of data for each market. Since some market indices contain missing values and/or are not calculated for the whole period, Table 2 provides an overview of the analyzed time period for each market. Potential biases of the results due to these shortcomings in the data are a typical problem in empirical studies analyzing emerging markets and have to be taken into account in the interpretation. In total, the study covers the following twelve emerging securitized real estate markets: Argentina (ARG), Austria (AUT), Finland (FIN), Hong Kong (HK), Italy (ITA), Malaysia (MAS), New Zealand (NZL), the Philippines (PH), Portugal (POR), Singapore (SIN), and South Africa (RSA). The markets are considered emerging not because they are emerging markets by the commonly used criteria but because their securitized real estate markets have not existed until recently, are relatively young, are not matured, have partly shown strong growth in securitized real estate markets for the last decade, and/or are characterized by low trading volume, limited liquidity, and low analysts' coverage as well as still maturing institutional and legal settings as opposed to the markets in e.g. Australia (AUS), Japan (JPN), the United Kingdom (UK), and the United States (US) - even if there is some heterogeneity between the emerging markets related to the institutional and legal settings in particular. The four developed markets are considered well suited to empirically analyze and test the different behavior of emerging and developed markets. An extended analysis for further emerging markets such as the Chinese, Indonesian, Mexican, and Russian markets is not applicable since the indices are not calculated for a sufficiently long time period and the sample periods are thus too short to provide useful and reliable insights. 
Table 2: List of the GPR Country Indices and their Data Availability

\begin{tabular}{lccc}
\hline Country & Index & Analyzed time period & Number of observations \\
\hline Argentina & ARG & $09 / 1993-03 / 2008$ & 175 \\
Austria & AUT & $01 / 1992-12 / 2009$ & 216 \\
Finland & FIN & $07 / 1999-12 / 2009$ & 126 \\
Hong Kong & HKG & $01 / 1992-12 / 2009$ & 216 \\
Italy & ITA & $01 / 1992-12 / 2009$ & 216 \\
Malaysia & MAS & $01 / 1992-12 / 2009$ & 216 \\
New Zealand & NZL & $01 / 1992-12 / 2009$ & 216 \\
Philippines & PHI & $01 / 1992-12 / 2009$ & 216 \\
Portugal & POR & $01 / 1992-02 / 2002$ & 122 \\
Singapore & SIN & $01 / 1992-12 / 2009$ & 216 \\
South Africa & RSA & $07 / 1997-12 / 2009$ & 150 \\
Spain & ESP & $01 / 1992-12 / 2007$ & 192 \\
\hline Australia & AUS & $01 / 1992-12 / 2009$ & 216 \\
Japan & JPN & $01 / 1992-12 / 2009$ & 216 \\
United Kingdom & UK & $01 / 1992-12 / 2009$ & 216 \\
United States & US & $01 / 1992-12 / 2009$ & 216 \\
\hline
\end{tabular}

The descriptive statistics for the monthly returns of the GPR country indices in local currency are presented in Table 3 and are based on continuously compounded monthly returns for the period for which data are available for each market. ${ }^{1}$ As can be seen, Spain and South Africa reach the highest average monthly returns. However, neither time series covers the whole sample period and the average returns might thus be more biased than those of the other markets. Considering the whole time period, Australia, Hong Kong, Singapore, and the U.S. show the highest average returns. In addition to the Argentinian market, the Asian markets are characterized by the highest standard deviation as well as by the highest range of returns. With the exception of the Japanese market, the Jarque-Bera test rejects the null hypothesis of normally distributed returns for all series with all return series exhibiting significant

\footnotetext{
1 Log differences of prices are used because, for small changes, they approximately equal the rate of return from continuous compounding. The GPR indices are calculated on a monthly basis only. Thus, daily or weekly return data are not available.
} 
leptokurtosis while the results on skewness deviate from each other and are not significant for all markets. ${ }^{2}$

Table 3: Descriptive Statistics of the Monthly GPR Country Index Returns

\begin{tabular}{lccccccc}
\hline Index & Mean & Min. & Max. & Std.dev. & Skewness & Kurtosis & J.-B. \\
\hline ARG & 0.0064 & -0.4329 & 0.3192 & 0.1250 & -0.2243 & 3.7648 & $5.7326^{*}$ \\
AUT & -0.0019 & -0.6403 & 0.4058 & 0.0886 & -2.7168 & 29.1338 & $6,412.5020^{* * *}$ \\
ESP & 0.0142 & -0.3359 & 0.2391 & 0.0731 & -0.6495 & 6.2469 & $97.8404^{* * *}$ \\
FIN & 0.0075 & -0.2506 & 0.3091 & 0.0744 & 0.0874 & 6.3700 & $59.7843^{* * *}$ \\
HKG & 0.0096 & -0.4485 & 0.4687 & 0.1078 & 0.1184 & 6.1982 & $92.5591^{* * *}$ \\
ITA & 0.0042 & -0.3053 & 0.2884 & 0.0749 & -0.2703 & 5.8863 & $77.6080^{* * *}$ \\
MAS & 0.0025 & -0.3854 & 0.4165 & 0.1191 & 0.1291 & 5.0512 & $38.4673^{* * *}$ \\
NZL & 0.0051 & -0.2140 & 0.1757 & 0.0445 & -0.1728 & 6.5374 & $113.6949^{* * *}$ \\
PHI & 0.0053 & -0.3075 & 0.4555 & 0.1003 & 0.3016 & 4.9362 & $37.0122^{* * *}$ \\
POR & 0.0039 & -0.1627 & 0.2354 & 0.0633 & 0.6794 & 4.3926 & $19.2449^{* * *}$ \\
RSF & 0.0187 & -0.2109 & 0.1658 & 0.0543 & -0.5440 & 5.2338 & $38.5859^{* * *}$ \\
SIN & 0.0071 & -0.3979 & 0.4851 & 0.1044 & -0.1942 & 6.5356 & $113.8645^{* * *}$ \\
\hline AUS & 0.0073 & -0.2438 & 0.1437 & 0.0444 & -1.5830 & 9.7173 & $496.3114^{* * *}$ \\
JPN & -0.0003 & -0.2201 & 0.1961 & 0.0800 & -0.0722 & 2.8838 & 0.3094 \\
UK & 0.0060 & -0.2551 & 0.2130 & 0.0606 & -0.7279 & 5.6146 & $80.6023^{* * *}$ \\
US & 0.0081 & -0.3861 & 0.2638 & 0.0603 & -1.8867 & 14.9220 & $1,407.3690^{* * *}$ \\
\hline
\end{tabular}

Notes: $* * * * *$, and $*$ represent significance at the $1 \%, 5 \%$, and $10 \%$ level, respectively, of the null hypothesis of normal distribution of the Jarque-Bera test statistic. The critical values of the $\chi^{2}$-distributed test statistic with two degrees of freedom are 9.21, 5.99, and 4.61 (Jarque and Bera, 1980).

\subsection{Results of Autocorrelation Tests}

The efficient market hypothesis in its weak-form version states that asset returns are not timedependent and are thus not autocorrelated. However, as can be gathered from Table 4, the results from estimating autocorrelations of the monthly index changes show mixed results with respect to the twelve emerging real estate markets. While the markets in Argentina, Hong Kong, Italy, New Zealand, the Philippines, Portugal, and South Africa show no or only slightly significant autocorrelation, the European markets in Austria, Finland, and Spain, as well as the markets in Malaysia and Singapore exhibit significant autocorrelation for several

2 Significance for skewness and leptokurtosis is tested by the method suggested by Urzúa (1996). 
orders while positive autocorrelation is dominant, indicating a general mean aversion process. However, the effect of significant first-order and higher-order autocorrelation is much more distinct for the developed markets in Australia, the U.K., and the U.S. The finding of at least short-term mean aversion is also reported for the broad stock markets, e.g. by Poterba and Summers (1988), and is explained by various causes such as common risk factors of stocks (systematic risk), by Lo and MacKinlay (1988) as well as French and Roll (1986), but it is worth emphasizing that autocorrelation in emerging securitized real estate markets is less significant than in developed markets. ${ }^{3}$

Table 4: Autocorrelation of Monthly GPR Country Index Returns

\begin{tabular}{lcccccc}
\hline Index & $\rho_{1}$ & $\rho_{2}$ & $\rho_{3}$ & $\rho_{6}$ & $\rho_{12}$ & $\rho_{24}$ \\
\hline ARG & 0.0756 & 0.0156 & -0.0684 & -0.1650 & -0.0419 & -0.0924 \\
AUT & $0.4247^{* * *}$ & $0.1467^{* * *}$ & $0.1353^{* * *}$ & $-0.2905^{* * *}$ & $0.0040^{* * *}$ & $-0.0665^{* * *}$ \\
ESP & $0.2196^{* * *}$ & $0.0710^{* * *}$ & $0.0085^{* *}$ & $0.0553^{* *}$ & $0.0062^{*}$ & 0.0027 \\
FIN & $0.2416^{* * *}$ & $0.0726^{* *}$ & $0.0621^{* *}$ & $-0.1282^{* * *}$ & $0.1030^{* * *}$ & $-0.0447^{* *}$ \\
HKG & $0.1203^{*}$ & -0.0192 & -0.0707 & -0.0153 & $-0.1288^{*}$ & -0.0287 \\
ITA & 0.1018 & 0.0078 & -0.0770 & 0.0555 & -0.0347 & 0.0179 \\
MAS & 0.0502 & 0.1315 & $-0.1418^{* *}$ & $-0.0028^{* *}$ & $-0.0521^{* * *}$ & $0.0418^{* * *}$ \\
NZL & $0.1238^{*}$ & -0.0569 & -0.0371 & 0.0819 & -0.0554 & 0.0176 \\
PHI & 0.0187 & -0.1002 & 0.0207 & -0.0235 & 0.1243 & -0.0645 \\
POR & -0.0230 & 0.0228 & 0.0304 & 0.0093 & -0.0702 & -0.1637 \\
RSF & 0.1627 & 0.0362 & 0.0173 & -0.1392 & 0.0215 & 0.0429 \\
SIN & $0.1748^{* *}$ & $-0.0014^{* *}$ & $-0.0446^{*}$ & 0.0151 & $-0.0152^{*}$ & -0.0834 \\
\hline AUS & $0.1762^{* * *}$ & $0.1087^{* * *}$ & $0.0634^{* *}$ & $-0.1003^{* * *}$ & $0.1946^{* * *}$ & $-0.0205^{* * *}$ \\
JPN & 0.0844 & -0.0413 & $0.0894^{* * *}$ & -0.1225 & 0.0682 & -0.0537 \\
UK & $0.2458^{* * *}$ & $0.0721^{* * *}$ & $0.1332^{* * *}$ & $-0.0470^{* * *}$ & $-0.0030^{* * *}$ & $0.0113^{* * *}$ \\
US & $0.1397^{* *}$ & $-0.1494^{* *}$ & $0.1360^{* * *}$ & $-0.2403^{* * *}$ & $0.1018^{* * *}$ & $-0.0728^{* * *}$ \\
\hline
\end{tabular}

Notes: $* * *, * *$, and $*$ indicates significance of the autocorrelation coefficients for lag $\mathrm{h}$ at the $1 \%, 5 \%$, and $10 \%$ level, respectively, with critical values from the $\chi^{2}$ distribution with $\mathrm{h}$ degrees of freedom.

3 In contrast, Campbell et al. (1997) consider positive autocorrelation to be a result of market microstructure. They argue that non-synchronous trading and bid-ask bounces induce spurious autocorrelation in the returns' series. 


\subsection{Results of Variance Ratio Tests}

Again, for the variance ratio tests we assume that return dependencies are particularly strong for markets with low trading volume and limited liquidity. Thus, it is expected that the emerging markets show more persistence than matured markets. The variance ratios are computed in intervals of two, three, and six months, as well as in intervals of twelve and 24 months.

With the exception of Portugal, the returns of all indices exhibit variance ratios greater than one, at least in the short run. This confirms the results of positive autocorrelation and mean aversion, respectively, from autocorrelation analysis. Again, however, only a few markets are characterized by highly significant variance ratios, namely Austria, Finland, Singapore, South Africa, and Spain for the emerging markets and Australia, the U.K., and the U.S. for the matured markets. With the exception of South Africa, the markets are identical to the markets with highly significant, short-term positive autorcorrelation. Long-term persistencies for up to one and/or two years are much weaker but still indicate mean aversion processes and only exist for Austria, Finland, Singapore, and Spain, as well as for Australia and the U.K.

Adjusting the tests for heteroscedasticity changes the results because the test statistics are formulated more restrictively. The most prominent changes can be found for the highly skewed markets such as the Austrian and the U.S. market, for which the formerly significant results are much weaker and/or significance disappears at all. Furthermore, considering multiple lag lenghts simultaneously results in a rejection of the random walk hypothesis for markets characterized by strong higher-order autocorrelation and long-term persistence in the variance ratios, namely Austria (not adjusted for heteroscedasticity), Finland, and Spain, as well as Australia and the U.K.

Summarizing the results from the different variance ratio tests, it can be stated that - in line with the results from autocorrelation analysis - the random walk hypothesis is rejected for the markets in Austria, Finland, and Spain in particular, as well as for South Africa and Singapore to some lesser extent. Nevertheless, over all, there is no indication that the emerging securitized real estate markets are less efficient than the more matured markets in Australia, Japan, the U.K., and the U.S 
Table 5: Variance Ratio Estimates and Variance Ratio Test Statistics for Monthly GRP Country Index Returns

\begin{tabular}{|c|c|c|c|c|c|c|}
\hline \multirow[t]{2}{*}{ Index } & \multicolumn{5}{|c|}{$\begin{array}{l}\text { Number q of Base Observations (Lags) } \\
\text { Aggregated to form Variance Ratio }\end{array}$} & \multirow{2}{*}{$\begin{array}{l}\text { SMM for } \boldsymbol{m}=\mathbf{5} \\
\max Z_{1}{ }^{*}(2, \ldots, 24) \\
\max Z_{2}{ }^{*}(2, \ldots, 24)\end{array}$} \\
\hline & $q=2$ & $q=3$ & $q=6$ & $q=12$ & $q=24$ & \\
\hline $\mathrm{ARG}$ & $\begin{array}{l}1.08 \\
(1.02) \\
{[0.79]}\end{array}$ & $\begin{array}{l}1.12 \\
(1.02) \\
{[0.80]}\end{array}$ & $\begin{array}{l}1.03 \\
(0.18) \\
{[0.14]}\end{array}$ & $\begin{array}{c}0.90 \\
(-0.34) \\
{[-0.30]}\end{array}$ & $\begin{array}{c}0.78 \\
(-0.54) \\
{[-0.50]}\end{array}$ & $\begin{array}{l}(1.02) \\
{[0.80]}\end{array}$ \\
\hline AUT & $\begin{array}{c}1.44 \\
(6.43)^{* * *} \\
{[1.56]}\end{array}$ & $\begin{array}{c}1.69 \\
(6.85)^{* * *} \\
{[1.74]^{*}}\end{array}$ & $\begin{array}{c}2.19 \\
(7.09)^{* * *} \\
{[2.05]^{* *}}\end{array}$ & $\begin{array}{c}1.80 \\
(3.13)^{* * *} \\
{[1.03]}\end{array}$ & $\begin{array}{l}1.52 \\
(1.40) \\
{[0.54]}\end{array}$ & $\begin{array}{c}(7.09)^{* * *} \\
{[2.05]}\end{array}$ \\
\hline ESP & $\begin{array}{c}1.23 \\
(3.21)^{* * *} \\
{[2.61]^{* * *}}\end{array}$ & $\begin{array}{c}1.36 \\
(3.37)^{* * *} \\
{[2.89]^{* * *}}\end{array}$ & $\begin{array}{c}1.45 \\
(2.52)^{* *} \\
{[2.29]^{* *}}\end{array}$ & $\begin{array}{c}1.46 \\
(1.70)^{*} \\
{[1.57]}\end{array}$ & $\begin{array}{l}1.51 \\
(1.29) \\
{[1.29]}\end{array}$ & $\begin{array}{l}(3.37)^{* * *} \\
{[2.89]^{* * *}}\end{array}$ \\
\hline FIN & $\begin{array}{c}1.25 \\
(2.84)^{* * *} \\
{[1.94]^{*}}\end{array}$ & $\begin{array}{c}1.41 \\
(3.05)^{* * *} \\
{[2.18]^{* *}}\end{array}$ & $\begin{array}{l}1.90 \\
(4.11)^{* * *} \\
{[3.13]^{* * *}}\end{array}$ & $\begin{array}{c}2.13 \\
(3.37)^{* * *} \\
{[2.55]^{* *}}\end{array}$ & $\begin{array}{c}2.65 \\
(3.38)^{* * *} \\
{[2.67]^{* * *}}\end{array}$ & $\begin{array}{l}(4.11)^{* * *} \\
{[3.13]^{* * *}}\end{array}$ \\
\hline $\mathrm{HKG}$ & $\begin{array}{c}1.13 \\
(1.89)^{*} \\
{[1.73]^{*}}\end{array}$ & $\begin{array}{l}1.17 \\
(1.63) \\
{[1.50]}\end{array}$ & $\begin{array}{l}1.11 \\
(0.66) \\
{[0.57]}\end{array}$ & $\begin{array}{l}1.16 \\
(0.62) \\
{[0.51]}\end{array}$ & $\begin{array}{c}0.81 \\
(-0.52) \\
{[-0.44]}\end{array}$ & $\begin{array}{l}(1.89) \\
{[1.73]}\end{array}$ \\
\hline ITA & $\begin{array}{l}1.11 \\
(1.64) \\
{[1.33]}\end{array}$ & $\begin{array}{l}1.16 \\
(1.59) \\
{[1.29]}\end{array}$ & $\begin{array}{l}1.25 \\
(1.48) \\
{[1.22]}\end{array}$ & $\begin{array}{l}1.39 \\
(1.54) \\
{[1.28]}\end{array}$ & $\begin{array}{c}1.69 \\
(1.85)^{*} \\
{[1.64]}\end{array}$ & $\begin{array}{l}(1.85) \\
{[1.64]}\end{array}$ \\
\hline MAS & $\begin{array}{l}1.06 \\
(0.88) \\
{[0.68]}\end{array}$ & $\begin{array}{c}1.18 \\
(1.73)^{*} \\
{[1.34]}\end{array}$ & $\begin{array}{c}1.09 \\
(0.56) \\
{[0.42]}\end{array}$ & $\begin{array}{l}1.31 \\
(1.22) \\
{[0.88]}\end{array}$ & $\begin{array}{l}1.08 \\
(0.21) \\
{[0.16]}\end{array}$ & $\begin{array}{l}(1.73) \\
{[1.34]}\end{array}$ \\
\hline NZL & $\begin{array}{c}1.13 \\
(1.88)^{*} \\
{[1.37]}\end{array}$ & $\begin{array}{l}1.14 \\
(1.36) \\
{[1.03]}\end{array}$ & $\begin{array}{l}1.05 \\
(0.28) \\
{[0.22]}\end{array}$ & $\begin{array}{c}1.09 \\
(0.34) \\
{[0.26]}\end{array}$ & $\begin{array}{c}0.98 \\
(-0.04) \\
{[-0.04]}\end{array}$ & $\begin{array}{l}(1.88) \\
{[1.37]}\end{array}$ \\
\hline PHI & $\begin{array}{l}1.03 \\
(0.41) \\
{[0.43]}\end{array}$ & $\begin{array}{c}0.98 \\
(-0.24) \\
{[-0.23]}\end{array}$ & $\begin{array}{c}0.95 \\
(-0.30) \\
{[-0.27]}\end{array}$ & $\begin{array}{c}0.80 \\
(-0.76) \\
{[-0.73]}\end{array}$ & $\begin{array}{c}0.81 \\
(-0.51) \\
{[-0.49]}\end{array}$ & $\begin{array}{l}(-0.76) \\
{[-0.73]}\end{array}$ \\
\hline POR & $\begin{array}{c}0.98 \\
(-0.27) \\
{[-0.28]}\end{array}$ & $\begin{array}{c}0.99 \\
(-0.05) \\
{[-0.05]}\end{array}$ & $\begin{array}{l}1.02 \\
(0.08) \\
{[0.09]}\end{array}$ & $\begin{array}{c}0.85 \\
(-0.44) \\
{[-0.47]}\end{array}$ & $\begin{array}{c}0.56 \\
(-0.88) \\
{[-0.93]}\end{array}$ & $\begin{array}{l}(-0.88) \\
{[-0.93]}\end{array}$ \\
\hline RSF & $\begin{array}{c}1.18 \\
(2.14)^{* *} \\
{[1.75]^{*}}\end{array}$ & $\begin{array}{c}1.27 \\
(2.24)^{* *} \\
{[1.84]^{*}}\end{array}$ & $\begin{array}{c}1.41 \\
(2.03)^{* *} \\
{[1.67]^{*}}\end{array}$ & $\begin{array}{l}1.28 \\
(0.93) \\
{[0.78]}\end{array}$ & $\begin{array}{l}1.02 \\
(0.04) \\
{[0.04]}\end{array}$ & $\begin{array}{l}(2.24) \\
{[1.84]}\end{array}$ \\
\hline SIN & $\begin{array}{c}1.19 \\
(2.72)^{* * *} \\
{[1.97]^{* *}}\end{array}$ & $\begin{array}{c}1.25 \\
(2.50)^{* *} \\
{[1.77]^{*}}\end{array}$ & $\begin{array}{c}1.32 \\
(1.87)^{*} \\
{[1.32]}\end{array}$ & $\begin{array}{c}1.42 \\
(1.65)^{*} \\
{[1.19]}\end{array}$ & $\begin{array}{l}1.33 \\
(0.88) \\
{[0.66]}\end{array}$ & $\begin{array}{c}(2.72)^{* *} \\
{[1.97]}\end{array}$ \\
\hline
\end{tabular}

Table 5 continues on the next page 


\begin{tabular}{lcccccc}
\hline Index & \multicolumn{5}{c}{$\begin{array}{c}\text { Number q of Base Observations (Lags) } \\
\text { Aggregated to form Variance Ratio }\end{array}$} & $\begin{array}{c}\text { SMM for } \boldsymbol{m}=5 \\
\operatorname{max~} \mathrm{Z}_{1}{ }^{*}(2, \ldots, 24)\end{array}$ \\
& $\mathrm{q}=2$ & $\mathrm{q}=3$ & $\mathrm{q}=6$ & $\mathrm{q}=12$ & $\mathrm{q}=24$ & $\max \mathrm{Z}_{2}(2, \ldots, 24)$ \\
\hline AUS & 1.19 & 1.33 & 1.78 & 2.34 & 2.70 & \\
& $(2.73)^{* * *}$ & $(3.25)^{* * *}$ & $(4.65)^{* * *}$ & $(5.24)^{* * *}$ & $(4.57)^{* * *}$ & $(5.24)^{* * *}$ \\
& {$[1.81]^{* *}$} & {$[2.06]^{* *}$} & {$[2.82]^{* * *}$} & {$[3.13]^{* * *}$} & {$[2.85]^{* * *}$} & {$[3.13]^{* * *}$} \\
JPN & 1.09 & 1.09 & 1.23 & 1.19 & 1.38 & \\
& $(1.26)$ & $(0.92)$ & $(1.35)$ & $(0.73)$ & $(1.02)$ & $(1.35)$ \\
& {$[1.19]$} & {$[0.87]$} & {$[1.27]$} & {$[0.71]$} & {$[1.03]$} & {$[1.27]$} \\
UK & 1.26 & 1.40 & 1.87 & 2.10 & 2.27 & \\
& $(3.76)^{* * *}$ & $(3.92)^{* * *}$ & $(5.16)^{* * *}$ & $(4.33)^{* * *}$ & $(3.40)^{* * *}$ & $(5.16)^{* * *}$ \\
& {$[2.82]^{* * *}$} & {$[3.00]^{* * *}$} & {$[3.75]^{* * *}$} & {$[3.18]^{* * *}$} & {$[2.72]^{* * *}$} & {$[3.75]^{* * *}$} \\
US & 1.15 & 1.10 & 1.39 & 1.31 & 1.39 & \\
& $(2.17)^{* *}$ & $(0.98)$ & $(2.34)^{* *}$ & $(1.20)$ & $(1.03)$ & $(2.17)$ \\
& {$[0.86]$} & {$[0.40]$} & {$[1.01]$} & {$[0.56]$} & {$[0.57]$} & {$[1.01]$} \\
\hline
\end{tabular}

Notes: ${ }^{* * *},{ }^{* *},{ }^{*}$ indicate significance at the $99 \%, 95 \%$, and $90 \%$ confidence level (rejection of the RWH). One month is used as a base observation interval; the varaince ratios, VR(q)s, are reported in the main rows. The homoscedasticity-consistent and heteroscedasticity-consistent test results are reported in parentheses $\left(Z_{1}(q)\right.$, $\left.\mathrm{Z}_{1}{ }^{*}(\mathrm{q})\right)$ and brackets $\left[\mathrm{Z}_{2}(\mathrm{q}), \mathrm{Z}_{2}{ }^{*}(\mathrm{q})\right]$, respectively. The critical values for multiple variance ratio tests $\mathrm{Z}_{1}{ }^{*}(\mathrm{q})$ and $\mathrm{Z}_{2}{ }^{*}(\mathrm{q})$ at the $1 \%, 5 \%$, and $10 \%$ significance level are 3.089, 2.569, and 2.311, respectively, according to Hahn and Hendrickson (1971) and Stoline and Ury (1979).

\subsection{Results of Runs Tests}

As mentioned above, both the autocorrelation tests and the variance ratio tests exhibit some shortcomings when applied to the analysis of market efficiency. Moreover, if the returngenerating process is non-linear, the autocorrelation coefficients and variance ratio tests are not a reliable measure to detect market (in-)efficiency, and non-autocorrelated financial market returns do not necessarily imply market efficiency (Lucas, 1978; Summers, 1986), especially because of the reported skewness and kurtosis of the return distributions in Table 3. Therefore, a direct test for market efficiency is employed which requires neither the assumption of normality of the underlying distribution nor a linear return-generating process. The results of the non-parametric runs test of independence between successive events in the time series of monthly index changes are presented in Table 6.

The test statistics indicate the rejection of a random walk for the markets in Austria, Finland, Italy, and South Africa at the $10 \%$ significance level for the emerging markets, as well as for the markets in Japan, the U.K., and the U.S. With the exception of Italy and Japan, these are the same markets for which the random walk hypothesis is rejected by at least one of the above parametric tests, whereas the test statistic for Italy is significant at the $10 \%$ level only. 
Thus, the results related to the efficient market hypothesis in its weak form do not change rigorously when focusing on a non-parametric runs test instead of parametric tests based on autocorrelations and variance ratios.

Table 6: Results from the Runs Test for Monthly GPR Country Index Returns

\begin{tabular}{lcccc}
\hline Index & Runs & Probability & Test Statistics \\
& $\mathbf{N}_{\text {Runs }}$ & $\begin{array}{c}\text { expected } \\
\text { E[Runs] }\end{array}$ & $\pi$ & \\
\hline ARG & 91 & 88 & 0.5204 & 0.6258 \\
AUT & 81 & 108 & 0.4913 & $-3.6006^{* * *}$ \\
ESP & 86 & 94 & 0.5771 & -1.0184 \\
FIN & 48 & 63 & 0.5400 & $-2.4958^{* *}$ \\
HKG & 95 & 108 & 0.5353 & -1.6198 \\
ITA & 95 & 108 & 0.5225 & $-1.6678^{*}$ \\
MAS & 101 & 108 & 0.5083 & -0.8802 \\
NZL & 102 & 108 & 0.5456 & -0.6212 \\
PHI & 111 & 108 & 0.5209 & 0.5011 \\
POR & 63 & 61 & 0.5246 & 0.4782 \\
RSF & 53 & 70 & 0.6345 & $-2.4706^{* *}$ \\
SIN & 101 & 108 & 0.5272 & -0.8387 \\
\hline AUS & 98 & 107 & 0.5653 & -1.0256 \\
JPN & 90 & 108 & 0.4986 & $-2.3813^{* *}$ \\
UK & 93 & 108 & 0.5393 & $-1.8712^{*}$ \\
US & 93 & 107 & 0.5533 & $-1.7867^{*}$ \\
\hline
\end{tabular}

Notes: ${ }^{* * *},{ }^{* *}$ and ${ }^{*}$ indicate significance at the $99 \%, 95 \%$, and $90 \%$ confidence level, respectively; critical values for the runs test at the $1 \%, 5 \%$, and $10 \%$ significance level are derived from standard normal distribution.

Table 7 summarizes the results from the conducted statistical tests. The main conclusions are as follows. First, the efficient market hypothesis in its weak form can not be rejected for most emerging securitized real estate markets. Second, the markets in Austria, Finland, Singapore, and Spain seem to be less efficient than the other emerging markets analyzed in this study. Third, in general, the efficient market hypothesis is rejected for all of the four analyzed developed securitized real estate markets by at least one statistical test. This result is surprising and stands in contrast to financial theory and empirical evidence from other 
markets, which find that inefficiencies are more distinctive in markets which are less capitalized and less developed, exhibit lower trading volume, lower coverage by analysts, and are situated within a less matured institutional and legal setting. Overall, according to the results of the statistical tests of the random walk hypothesis, emerging securitized real estate markets can not be considered less efficient than matured and more developed securitized real estate markets.

Table 7: Summary of the Results of Testing the Efficient Market Hypothesis

\begin{tabular}{lcccc}
\hline Index & $\begin{array}{c}\text { Autocorrelation } \\
\text { Test }\end{array}$ & $\begin{array}{c}\text { Variance Ratio } \\
\text { Test }\end{array}$ & $\begin{array}{c}\text { Multiple Variance } \\
\text { Ratio Test }\end{array}$ & Runs Test \\
\hline ARG & $\mathrm{O}$ & $\mathrm{O}$ & $\mathrm{O}$ & $\mathrm{O}$ \\
AUT & $\mathrm{X}$ & $\mathrm{X}$ & $\mathrm{O}$ & $\mathrm{X}$ \\
ESP & $\mathrm{X}$ & $\mathrm{X}$ & $\mathrm{X}$ & $\mathrm{O}$ \\
FIN & $\mathrm{X}$ & $\mathrm{X}$ & $\mathrm{X}$ & $\mathrm{X}$ \\
HKG & $\mathrm{O}$ & $\mathrm{O}$ & $\mathrm{O}$ & $\mathrm{O}$ \\
ITA & $\mathrm{O}$ & $\mathrm{O}$ & $\mathrm{O}$ & $\mathrm{O}$ \\
MAS & $\mathrm{O}$ & $\mathrm{O}$ & $\mathrm{O}$ & $\mathrm{O}$ \\
NZL & $\mathrm{O}$ & $\mathrm{O}$ & $\mathrm{O}$ & $\mathrm{O}$ \\
PHI & $\mathrm{O}$ & $\mathrm{O}$ & $\mathrm{O}$ & $\mathrm{O}$ \\
POR & $\mathrm{O}$ & $\mathrm{O}$ & $\mathrm{O}$ & $\mathrm{O}$ \\
RSF & $\mathrm{O}$ & $\mathrm{O}$ & $\mathrm{O}$ & $\mathrm{X}$ \\
SIN & $\mathrm{X}$ & $\mathrm{X}$ & $\mathrm{X}$ & $\mathrm{O}$ \\
\hline AUS & $\mathrm{X}$ & $\mathrm{X}$ & $\mathrm{X}$ & $\mathrm{O}$ \\
JPN & $\mathrm{O}$ & $\mathrm{O}$ & $\mathrm{O}$ & $\mathrm{X}$ \\
UK & $\mathrm{X}$ & $\mathrm{X}$ & $\mathrm{X}$ & $\mathrm{O}$ \\
US & $\mathrm{X}$ & $\mathrm{O}$ & $\mathrm{O}$ & $\mathrm{O}$ \\
\hline N & & & &
\end{tabular}

Notes: X denotes rejection of the RWH at the $5 \%$ significance level according to the first-order autocorrelation coefficient, the runs test, the VR tests for one or more $\mathrm{q}$ observation intervals with $\mathrm{q}=2,3,6,12$, and 24 assuming heteroscedasticity, and for multiple VR tests for $\mathrm{m}=5$; O denotes acceptance of the null hypothesis.

\section{Implications for Trading Strategies}

Following the definition by Fama (1970), asset markets can be weak-form efficient from a more practical perspective even if the efficient market hypothesis is rejected by statistical tests and asset prices do not reflect all relevant market information. Thus, the rejection of the 
weak-form version of market efficiency by itself does not postulate market inefficiency. Although inefficiencies seem to be statistically detected, they might be too small for investors yielding excess returns by implementing trading strategies based upon historical price information. This means that rejecting the random walk hypothesis does not necessarily contradict the efficient market hypothesis as long as the implementation of a trading strategy is not beneficial. Vice versa, it might also be the case that the random walk hypothesis is not rejected, but that there is a pattern in the price or return series which can be exploited by an investor in order to earn excess returns compared to a buy-and-hold strategy. Thus, further methods must be introduced to evaluate particular strategies and to provide more direct evidence of market inefficiencies. Technical analysis can therefore serve as a control of, or complement, earlier statistical testing methods.

The tested trading strategies are based on moving averages. The application of moving averages does not require any assumption on linearity in returns and the trading strategy is of simple construction, allows for out-of-sample analysis, and is thus well suited as a basis for investors' strategies. Tax effects and transaction costs are not considered.

Moving averages are applied to distinguish between long-term trends and short-term oscillations, thus acting as trend indicators. In practice, the average index price is calculated from past index prices. The number of relevant historical index values depends on the period examined. Moving averages differ with respect to the length of time (e.g., three, six, twelve months) and also with regard to the calculation of the mean. In the simplest model, the arithmetic mean is used. The implementation of more sophisticated models, i.e. models applying linearly or exponentially weighted averages, might be possible as well, but differences between these approaches are rather small. In addition to the long-term twelvemonth window, moving averages for three and six months are calculated. This might be an advantage for indices that are more volatile and less persistent.

A trading signal occurs immediately at the breakthrough of the moving average line. A buying signal occurs if the index value breaks through its moving average bottom-up; a selling signal occurs when the moving average is breached top-down. Again, the charttechnical model is compared with the buy-and-hold strategy. The technical model is of advantage when it generates higher returns than a simple buy-and-hold strategy.

In general, two scenarios are considered. In the first case, short selling is not allowed, which is more realistic with respect to the actual situation at the securitized real estate markets 
where short selling is not realizable for the majority of markets. In the second case, we do allow for short selling. This case is incorporated by assuming short selling instead of zero returns for periods in which the trading signal recommends selling the market. Hence, the investor is not neutral in such cases but actively engaged in the market. For inefficient markets for which moving averages are a well-functioning indicator, the second scenario should result in higher excess returns than the first scenario.

The sample period is identical to the sample for the tests of the random walk hypothesis. The first twelve months of each time series are required to compute the moving average based on the twelve-month line and serve as decision criteria for the positioning. Therefore, the results of the trading strategies based on moving averages differ by twelve observations from the sample period for the tests of the random walk hypothesis.

The total nominal returns of both strategies, the one in which short selling is not allowed and the one in which short selling is possible, are shown in Table 8. With the exception of the markets in Portugal and South Africa, all analyzed securitized real estate market indices show higher returns for at least one strategy based on moving averages than for a continuous market investment. This seems to stand in contrast to the results of the test on the random walk hypothesis and testifies a well-functioning forecast for moving averages.

The best relative performance of the trading strategy, compared to the buy-and-hold strategy, is reached by the Asian markets as well as the markets in Austria and Finland, but the reasons might be different. While the results are in line with a rejection of the random walk hypothesis for the latter two markets, the Asian markets are characterized by the highest volatility of all markets. The argument that volatility drives the trading strategy is also supported by the fact that the trading strategy for the Asian markets works better in the short run than in the long run. For other markets such as Finland, Italy, New Zealand, and even Australia, the U.K., and the U.S., excess returns of the trading strategy are higher when applying long-term instead of short-term moving averages. This result also documents that persistence is stronger in these markets.

For the Asian markets, it is also obvious that strategies allowing for short selling do not improve the performance over the performance of the strategy without short selling. However, the opposite applies to the markets in Austria, Finland, and Italy, as well as those in Australia and the U.K. With the exception of Italy, this result is in line with the statistical tests and the assumption that allowing for short selling should improve the performance when 
inefficiencies are strong, since short selling allows for participation in upward-moving markets as well as in downward-moving markets. Furthermore, for all markets mentioned, the efficient market hypothesis is rejected by at least two tests.

As discussed, while the statistical tests do not reject the random walk hypothesis for most emerging markets, the technical analysis depicts trading strategies by which investors might be able to generate excess returns compared to a buy-and-hold strategy. Thus, the answer to the question of weak-form efficiency of emerging securitized real estate markets is ambiguous and no final conclusion can be drawn. In defense of the results of the statistical tests, it has to be mentioned that the trading strategies are built on a different set of information than the statistical tests, that transaction costs as well as bid-ask spreads are neglected, and that tax issues are not considered. Thus, it is not assured that the calculated excess returns can be effectively realized by investors. Furthermore, the results from both the statistical tests and the implementation of trading strategies postulate that the emerging securitized real estate markets are not at all less efficient than the matured securitized real estate markets in Australia, Japan, the U.K., and the U.S. 
Table 8: Total Nominal Returns from a Buy-and-Hold Strategy Compared to Trading Strategies Based on Moving Averages (MA)

\begin{tabular}{|c|c|c|c|c|}
\hline Index & Buy-and-Hold & 3-Month MA & 6-Month MA & 12-Month MA \\
\hline $\mathrm{ARG}$ & $72.09 \%$ & $\begin{array}{c}71.72 \% \\
-49.25 \%\end{array}$ & $\begin{array}{c}6.17 \% \\
-83.17 \%\end{array}$ & $\begin{array}{l}113.56 \% \\
-35.14 \%\end{array}$ \\
\hline AUT & $-31.90 \%$ & $\begin{array}{l}288.56 \% \\
790.53 \%\end{array}$ & $\begin{array}{l}302.79 \% \\
858.26 \%\end{array}$ & $\begin{array}{l}150.80 \% \\
177.55 \%\end{array}$ \\
\hline ESP & $2,084.59 \%$ & $\begin{array}{l}2,686.85 \% \\
2,474.84 \%\end{array}$ & $\begin{array}{l}2,413.00 \% \\
2,190.07 \%\end{array}$ & $\begin{array}{c}1,608.07 \% \\
974.19 \%\end{array}$ \\
\hline FIN & $220.61 \%$ & $\begin{array}{l}441.31 \% \\
455.65 \%\end{array}$ & $\begin{array}{l}549.23 \% \\
856.66 \%\end{array}$ & $\begin{array}{l}558.43 \% \\
894.91 \%\end{array}$ \\
\hline HKG & $429.44 \%$ & $\begin{array}{c}1107.55 \% \\
781.03 \%\end{array}$ & $\begin{array}{l}672.72 \% \\
120.95 \%\end{array}$ & $\begin{array}{c}586.17 \% \\
61.17 \%\end{array}$ \\
\hline ITA & $173.84 \%$ & $\begin{array}{l}328.64 \% \\
285.43 \%\end{array}$ & $\begin{array}{l}375.64 \% \\
377.80 \%\end{array}$ & $\begin{array}{l}535.52 \% \\
743.21 \%\end{array}$ \\
\hline MAS & $64.65 \%$ & $\begin{array}{l}538.97 \% \\
231.65 \%\end{array}$ & $\begin{array}{l}386.88 \% \\
151.61 \%\end{array}$ & $\begin{array}{l}113.74 \% \\
-59.80 \%\end{array}$ \\
\hline NZL & $214.51 \%$ & $\begin{array}{c}140.08 \% \\
55.52 \%\end{array}$ & $\begin{array}{l}318.26 \% \\
375.69 \%\end{array}$ & $\begin{array}{l}239.97 \% \\
204.28 \%\end{array}$ \\
\hline PHI & $141.59 \%$ & $\begin{array}{l}390.20 \% \\
172.22 \%\end{array}$ & $\begin{array}{c}184.38 \% \\
5.32 \%\end{array}$ & $\begin{array}{c}63.13 \% \\
-70.96 \%\end{array}$ \\
\hline POR & $152.68 \%$ & $\begin{array}{c}7.55 \% \\
-65.17 \%\end{array}$ & $\begin{array}{c}2.82 \% \\
-67.34 \%\end{array}$ & $\begin{array}{c}19.93 \% \\
-53.90 \%\end{array}$ \\
\hline RSF & $1,450.75 \%$ & $\begin{array}{c}1,242.69 \% \\
828.80 \%\end{array}$ & $\begin{array}{c}1,307.38 \% \\
984.91 \%\end{array}$ & $\begin{array}{c}1,128.54 \% \\
713.94 \%\end{array}$ \\
\hline SIN & $443.28 \%$ & $\begin{array}{c}1,109.98 \% \\
497.44 \%\end{array}$ & $\begin{array}{l}935.34 \% \\
293.47 \%\end{array}$ & $\begin{array}{c}649.22 \% \\
80.53 \%\end{array}$ \\
\hline AUS & $348.99 \%$ & $\begin{array}{l}272.29 \% \\
144.44 \%\end{array}$ & $\begin{array}{l}529.09 \% \\
607.58 \%\end{array}$ & $\begin{array}{l}628.79 \% \\
849.30 \%\end{array}$ \\
\hline JPN & $43.56 \%$ & $\begin{array}{c}111.03 \% \\
57.02 \%\end{array}$ & $\begin{array}{l}170.71 \% \\
150.42 \%\end{array}$ & $\begin{array}{l}70.24 \% \\
-7.00 \%\end{array}$ \\
\hline UK & $335.12 \%$ & $\begin{array}{l}752.81 \% \\
997.53 \%\end{array}$ & $\begin{array}{l}1,252.74 \% \\
2,765.14 \%\end{array}$ & $\begin{array}{l}742.03 \% \\
976.92 \%\end{array}$ \\
\hline US & $418.90 \%$ & $\begin{array}{c}242.46 \% \\
58.27 \%\end{array}$ & $\begin{array}{l}644.73 \% \\
563.69 \%\end{array}$ & $\begin{array}{l}658.27 \% \\
578.11 \%\end{array}$ \\
\hline
\end{tabular}

Notes: The results from allowing for short selling are shown in italics.

As a further robustness check on the results of technical trading strategies, statistical tests are conducted to test whether the mean returns following from buy indication and sell indication are significantly different from the unconditional mean and whether the mean returns 
following buy indication are significantly higher than those from sell indication. We apply a test suggested and conducted by Brock et al. (1992) to analyze market efficiency and evaluating trading strategies for the U.S. stock market. The results of the statistical tests are reported in Table 9. As can be seen, the results mainly confirm the results from the tests challenging the random walk hypothesis in section 3 as well as the results from the technical analysis by tendency. First, with the exception of the securitized real estate market in Portugal and one strategy for the markets in Argentina and the Philippines, the excess returns are positive following a buying signal and are negative after a selling indication, as is expected by theory. Second, the markets in Austria, Finland, Italy, and Spain, as well as the markets in Australia, the U.K., and the U.S. are characterized by the most significant differences between the mean results following from buy indication or sell indication. The other markets do not show highly significant results. Third, all markets for which strategies allowing for short selling perform better than more restricted strategies are characterized by significant differences between mean returns from buy indication and sell indication. Fourth, for Austria, Finland, and Italy, as well as for Australia, the U.K., and the U.S., excess returns for strategies based on long-term moving averages are higher and more significant than for those based on short-term moving averages. The results for the emerging securitized real estate markets in Argentina, the Asia-Pacific region, and South Africa are only slightly significant in a few cases and are not significant on the common significance levels at all by majority. In general, the results of the conducted statistical tests confirm the empirical findings from the previous analysis and thus also state that emerging securitized real estate markets can not be considered less efficient than matured markets. 
Table 9: Statistical Tests on the Results of the Applied Technical Trading Rules

\begin{tabular}{|c|c|c|c|c|}
\hline Index & Applied Strategy & Buy & Sell & Buy-Sell \\
\hline \multirow[t]{3}{*}{ ARG } & 3-Month MA & $\begin{array}{c}0.4016 \% \\
(0.2386)\end{array}$ & $\begin{array}{c}-0.3825 \\
(-0.2310)\end{array}$ & $\begin{array}{c}0.7841 \% \\
(0.4067)\end{array}$ \\
\hline & 6-Month MA & $\begin{array}{c}-0.3316 \% \\
(-0.2026)\end{array}$ & $\begin{array}{c}0.3747 \% \\
(0.2198)\end{array}$ & $\begin{array}{c}-0.7063 \% \\
(-0.3658)\end{array}$ \\
\hline & 12-Month MA & $\begin{array}{c}0.3532 \% \\
(0.2197)\end{array}$ & $\begin{array}{c}-0.4513 \% \\
(-0.2587)\end{array}$ & $\begin{array}{c}0.8046 \% \\
(0.4144)\end{array}$ \\
\hline \multirow[t]{3}{*}{ AUT } & 3-Month MA & $\begin{array}{c}0.1819 \% \\
(0.3721)\end{array}$ & $\begin{array}{c}-0.3746 \% \\
(-0.5997)\end{array}$ & $\begin{array}{c}0.5564 \% \\
(0.8419)\end{array}$ \\
\hline & 6-Month MA & $\begin{array}{c}0.4205 \% \\
(0.8884)\end{array}$ & $\begin{array}{l}-1.2698 \% \\
(-1.8281)^{*}\end{array}$ & $\begin{array}{l}1.6903 \% \\
(2.3569)^{* *}\end{array}$ \\
\hline & 12-Month MA & $\begin{array}{c}0.4112 \% \\
(0.8886)\end{array}$ & ${ }^{-1.8070}(-2.3049)^{* *}$ & $\begin{array}{l}2.2182 \% \\
(2.7804)^{* * *}\end{array}$ \\
\hline \multirow[t]{3}{*}{ ESP } & 3-Month MA & $\begin{array}{c}1.0074 \% \\
(1.2399)\end{array}$ & $\begin{array}{l}-2.0832 \% \\
(-2.0033)^{* *}\end{array}$ & $\begin{array}{l}3.0906 \% \\
(2.8098)^{* * *}\end{array}$ \\
\hline & 6-Month MA & $\begin{array}{c}0.8287 \% \\
(1.0345)\end{array}$ & $\begin{array}{l}-2.0013 \% \\
(-1.8474)^{*}\end{array}$ & $\begin{array}{l}2.8300 \% \\
(2.4978)^{* *}\end{array}$ \\
\hline & 12-Month MA & $\begin{array}{c}0.5531 \% \\
(0.6889)\end{array}$ & $\begin{array}{c}-1.3009 \% \\
(-1.2095)\end{array}$ & $\begin{array}{l}1.8540 \% \\
(1.6453)\end{array}$ \\
\hline \multirow[t]{3}{*}{ FIN } & 3-Month MA & $\begin{array}{c}1.2974 \% \\
(1.0912)\end{array}$ & $\begin{array}{c}-1.9460 \% \\
(-1.4287)\end{array}$ & $\begin{array}{l}3.2434 \% \\
(2.1824)^{* *}\end{array}$ \\
\hline & 6-Month MA & $\begin{array}{c}1.4287 \% \\
(1.2329)\end{array}$ & $\begin{array}{c}-2.6788 \% \\
(1.8691)^{*}\end{array}$ & $\begin{array}{l}4.1074 \% \\
(2.6870)^{* * *}\end{array}$ \\
\hline & 12-Month MA & $\begin{array}{c}1.2815 \% \\
(1.1274)\end{array}$ & $\begin{array}{l}-2.9291 \% \\
(-1.9434)^{*}\end{array}$ & $\begin{array}{l}4.2106 \% \\
(2.6610)^{* * *}\end{array}$ \\
\hline \multirow[t]{3}{*}{$\mathrm{HKG}$} & 3-Month MA & $\begin{array}{c}1.2810 \% \\
(0.9817)\end{array}$ & $\begin{array}{c}-1.7031 \% \\
(-1.1867)\end{array}$ & $\begin{array}{l}2.9841 \% \\
(1.8779)^{*}\end{array}$ \\
\hline & 6-Month MA & $\begin{array}{c}0.6778 \% \\
(0.5264)\end{array}$ & $\begin{array}{c}-0.9963 \% \\
(-0.6800)\end{array}$ & $\begin{array}{l}1.6741 \% \\
(1.0448)\end{array}$ \\
\hline & 12-Month MA & $\begin{array}{c}0.4196 \% \\
(0.3331)\end{array}$ & $\begin{array}{c}-0.7428 \% \\
(-0.4864)\end{array}$ & $\begin{array}{l}1.1624 \% \\
(0.7098)\end{array}$ \\
\hline \multirow[t]{3}{*}{ ITA } & 3-Month MA & $\begin{array}{c}0.7611 \% \\
(0.8521)\end{array}$ & $\begin{array}{c}-0.9725 \% \\
(-1.0032)\end{array}$ & $\begin{array}{c}1.7336 \% \\
(1.6067)\end{array}$ \\
\hline & 6-Month MA & $\begin{array}{c}0.8612 \% \\
(0.9615)\end{array}$ & $\begin{array}{c}-1.0789 \% \\
(-1.1172)\end{array}$ & $\begin{array}{l}1.9401 \% \\
(1.8002)^{*}\end{array}$ \\
\hline & 12-Month MA & $\begin{array}{c}1.3127 \% \\
(1.4177)\end{array}$ & $\begin{array}{c}-1.3255 \% \\
(-1.4269)\end{array}$ & $\begin{array}{l}2.6382 \% \\
(2.4635)^{* *}\end{array}$ \\
\hline
\end{tabular}

Table 9 continues on the next page 


\begin{tabular}{|c|c|c|c|c|}
\hline Index & Applied Strategy & Buy & Sell & Buy-Sell \\
\hline \multirow[t]{3}{*}{ MAS } & 3-Month MA & $\begin{array}{c}1.4049 \% \\
(0.9282)\end{array}$ & $\begin{array}{c}-1.4187 \% \\
(-0.9343)\end{array}$ & $\begin{array}{c}2.8236 \% \\
(1.6130)\end{array}$ \\
\hline & 6-Month MA & $\begin{array}{c}1.0678 \% \\
(0.7273)\end{array}$ & $\begin{array}{c}-1.3116 \% \\
(-0.8340)\end{array}$ & $\begin{array}{c}2.3794 \% \\
(1.3521)\end{array}$ \\
\hline & 12-Month MA & $\begin{array}{c}0.2485 \% \\
(0.1712)\end{array}$ & $\begin{array}{c}-0.3304 \% \\
(-0.2069)\end{array}$ & $\begin{array}{c}0.5790 \% \\
(0.3274)\end{array}$ \\
\hline \multirow[t]{3}{*}{ NZL } & 3-Month MA & $\begin{array}{c}0.1327 \% \\
(0.2705)\end{array}$ & $\begin{array}{c}-0.2116 \% \\
(-0.3688)\end{array}$ & $\begin{array}{c}0.3443 \% \\
(0.5538)\end{array}$ \\
\hline & 6-Month MA & $\begin{array}{c}0.4683 \% \\
(0.9817)\end{array}$ & $\begin{array}{c}-0.9646 \% \\
(-1.5822)\end{array}$ & $\begin{array}{l}1.4330 \% \\
(2.2213)^{* *}\end{array}$ \\
\hline & 12-Month MA & $\begin{array}{c}0.2806 \% \\
(0.5933)\end{array}$ & $\begin{array}{c}-0.6326 \% \\
(-1.0136)\end{array}$ & $\begin{array}{c}0.9132 \% \\
(1.3924)\end{array}$ \\
\hline \multirow[t]{3}{*}{ PHI } & 3-Month MA & $\begin{array}{c}1.0694 \% \\
(0.8544)\end{array}$ & $\begin{array}{c}-1.0590 \% \\
(-0.8489)\end{array}$ & $\begin{array}{c}2.1284 \% \\
(1.4751)\end{array}$ \\
\hline & 6-Month MA & $\begin{array}{c}0.4470 \% \\
(0.3704)\end{array}$ & $\begin{array}{c}-0.5600 \% \\
(-0.4304)\end{array}$ & $\begin{array}{c}1.0069 \% \\
(0.6935)\end{array}$ \\
\hline & 12-Month MA & $\begin{array}{c}-0.1330 \% \\
(-0.1111)\end{array}$ & $\begin{array}{c}0.1769 \% \\
(0.1343)\end{array}$ & $\begin{array}{c}-0.3099 \% \\
(-0.2126)\end{array}$ \\
\hline \multirow[t]{3}{*}{ POR } & 3-Month MA & $\begin{array}{c}-0.7176 \% \\
(-0.6712)\end{array}$ & $\begin{array}{c}0.6558 \% \\
(0.6321)\end{array}$ & $\begin{array}{c}-1.3734 \% \\
(-1.1287)\end{array}$ \\
\hline & 6-Month MA & $\begin{array}{c}-0.8054 \% \\
(-0.7806)\end{array}$ & $\begin{array}{c}0.9138 \% \\
(0.8492)\end{array}$ & $\begin{array}{c}-1.7192 \% \\
(-1.4115)\end{array}$ \\
\hline & 12-Month MA & $\begin{array}{c}-0.5408 \% \\
(-0.5327)\end{array}$ & $\begin{array}{c}0.6843 \% \\
(0.6230)\end{array}$ & $\begin{array}{c}-1.2251 \% \\
(-1.0009)\end{array}$ \\
\hline \multirow[t]{3}{*}{ RSF } & 3-Month MA & $\begin{array}{c}0.6627 \% \\
(0.9046)\end{array}$ & $\begin{array}{c}-1.5306 \% \\
(-1.5698)\end{array}$ & $\begin{array}{l}2.1933 \% \\
(2.1443)^{* *}\end{array}$ \\
\hline & 6-Month MA & $\begin{array}{c}0.3138 \% \\
(0.4485)\end{array}$ & $\begin{array}{c}-1.4308 \% \\
(-1.1894)\end{array}$ & $\begin{array}{c}1.7446 \% \\
(1.4266)\end{array}$ \\
\hline & 12-Month MA & $\begin{array}{c}0.1484 \% \\
(0.2131)\end{array}$ & $\begin{array}{c}-0.7483 \% \\
(-0.6003)\end{array}$ & $\begin{array}{c}0.8967 \% \\
(0.7094)\end{array}$ \\
\hline \multirow[t]{3}{*}{ SIN } & 3-Month MA & $\begin{array}{c}1.0806 \% \\
(0.8753)\end{array}$ & $\begin{array}{c}-1.5566 \% \\
(-1.1158)\end{array}$ & $\begin{array}{l}2.6373 \% \\
(1.7244)^{*}\end{array}$ \\
\hline & 6-Month MA & $\begin{array}{c}0.9167 \% \\
(0.7406)\end{array}$ & $\begin{array}{c}-1.2942 \% \\
(-0.9316)\end{array}$ & $\begin{array}{c}2.2109 \% \\
(1.4482)\end{array}$ \\
\hline & 12-Month MA & $\begin{array}{c}0.3996 \% \\
(0.3341)\end{array}$ & $\begin{array}{c}-0.7543 \% \\
(-0.5086)\end{array}$ & $\begin{array}{c}1.1539 \% \\
(0.7300)\end{array}$ \\
\hline
\end{tabular}

Table 9 continues on the next page 


\begin{tabular}{|c|c|c|c|c|}
\hline Index & Applied Strategy & Buy & Sell & Buy-Sell \\
\hline \multirow[t]{3}{*}{ AUS } & 3-Month MA & $\begin{array}{c}0.1819 \% \\
(0.3721)\end{array}$ & $\begin{array}{l}-0.3746 \% \\
(-0.5997)\end{array}$ & $\begin{array}{c}0.5564 \% \\
(0.8419)\end{array}$ \\
\hline & 6-Month MA & $\begin{array}{c}0.4205 \% \\
(0.8884)\end{array}$ & $\begin{array}{l}-1.2698 \% \\
(-1.8281)^{*}\end{array}$ & $\begin{array}{l}1.6903 \% \\
(2.3569)^{* *}\end{array}$ \\
\hline & 12-Month MA & $\begin{array}{c}0.4112 \% \\
(0.8886)\end{array}$ & $\begin{array}{l}-1.8070 \% \\
(-2.3049)^{* *}\end{array}$ & $\begin{array}{l}2.2182 \% \\
(2.7804)^{* * *}\end{array}$ \\
\hline \multirow[t]{3}{*}{ JPN } & 3-Month MA & $\begin{array}{c}0.5397 \% \\
(0.5688)\end{array}$ & $\begin{array}{c}-0.5241 \% \\
(-0.5578)\end{array}$ & $\begin{array}{l}1.0638 \% \\
(0.9756)\end{array}$ \\
\hline & 6-Month MA & $\begin{array}{c}0.6991 \% \\
(0.7510)\end{array}$ & $\begin{array}{l}-0.7633 \% \\
(-0.7963)\end{array}$ & $\begin{array}{l}1.4624 \% \\
(1.3400)\end{array}$ \\
\hline & 12-Month MA & $\begin{array}{c}0.2070 \% \\
(0.2257)\end{array}$ & $\begin{array}{c}-0.2493 \% \\
(-0.2555)\end{array}$ & $\begin{array}{c}0.4563 \% \\
(0.4167)\end{array}$ \\
\hline \multirow[t]{3}{*}{ UK } & 3-Month MA & $\begin{array}{c}0.9083 \% \\
(1.3780)\end{array}$ & $\begin{array}{l}-1.4789 \% \\
(1.9045)^{*}\end{array}$ & $\begin{array}{l}2.3872 \% \\
(2.8430)^{* * *}\end{array}$ \\
\hline & 6-Month MA & $\begin{array}{l}1.2035 \% \\
(1.8476)^{*}\end{array}$ & $\begin{array}{l}-2.1761 \% \\
(-2.7354)^{* * *}\end{array}$ & $\begin{array}{l}3.3796 \% \\
(3.9697)^{* * *}\end{array}$ \\
\hline & 12-Month MA & $\begin{array}{c}0.7969 \% \\
(1.2318)\end{array}$ & $\begin{array}{l}-1.5369 \% \\
(-1.9021)^{*}\end{array}$ & $\begin{array}{l}2.3338 \% \\
(2.7147)^{* * *}\end{array}$ \\
\hline \multirow[t]{3}{*}{ US } & 3-Month MA & $\begin{array}{c}0.1012 \% \\
(0.1529)\end{array}$ & $\begin{array}{l}-0.1830 \% \\
(-0.2264)\end{array}$ & $\begin{array}{c}0.2842 \% \\
(0.3286)\end{array}$ \\
\hline & 6-Month MA & $\begin{array}{c}0.5629 \% \\
(0.8619)\end{array}$ & $\begin{array}{c}-1.1594 \% \\
(-1.3891)\end{array}$ & $\begin{array}{l}1.7224 \% \\
(1.9502)^{*}\end{array}$ \\
\hline & 12-Month MA & $\begin{array}{c}0.4660 \% \\
(0.7284)\end{array}$ & $\begin{array}{c}-1.2099 \% \\
(-1.3623)\end{array}$ & $\begin{array}{l}1.6759 \% \\
(1.8126)^{*}\end{array}$ \\
\hline
\end{tabular}

Notes: Numbers in parentheses are standard t-ratios testing the difference of the mean return from buy indication (buy) and from sell indication (sell), respectively, from the unconditional mean return per month as well as buy minus sell (buy-sell) from zero. ${ }^{* * *},{ }^{* *}$ and ${ }^{*}$ indicate significance at the $99 \%, 95 \%$, and $90 \%$ confidence level, respectively.

\section{Conclusion}

This paper challenges the efficient market hypothesis for emerging real estate stock markets in its weak form by focusing on the information set of historical prices or return series and by testing the random walk hypothesis. This study analyzes the behavior of monthly index returns for twelve emerging securitized real estate markets around the world and for four developed markets as a control group over the period from January 1992 to December 2009. In addition to the parametric tests based on autocorrelation and variance ratios, we also conduct a non-parametric runs test for market efficiency. The results for the emerging real 
estate stock markets are quite interesting and to some extent surprising against the background of the results of Schindler et al. (2009) for mostly developed real estate stock markets. Schindler et al. (2009) find that the efficient market hypothesis in its weak form is mainly rejected for securitized real estate markets. Their analysis is based on 14 international real estat stock markets and a sample period similar to that in the present study.

In contrast to these findings, this study shows that the weak-form version of the efficient market hypothesis cannot be rejected for most emerging real estate markets, particularly for the Asia-Pacific, the Argentinian, and the South African markets. However, the efficient market hypothesis is mainly rejected for the low-capitalized European markets and the group of developed and large capitalized markets such as Australia, the United Kingdom, and the United States. These results contradict the general empirical findings from international stock and bond markets, where those markets which are more sophisticated and higher-capitalized, which have a higher trading volume, higher analysts' coverage, and are situated in a matured institutional and legal setting, seem to be more efficient than emerging markets. Serrano and Hoesli (2009) argue that the reason for the greater predictability of securitized real estate returns in matured REIT markets might be their more stable income returns and their distribution requirements to qualify for tax transparency. However, Serrano and Hoesli (2009) do not explicitly analyze emerging securitized real estate markets and leave research on the explaining factors making REITs more predictable than non-REITs to future studies.

Thus, in support of the markets in Argentina, South Africa, and the Asia-Pacific region, it can be stated - from a statistical point of view - that prices do well reflect at least publicly available information, and that information processing in these markets via the asset pricing process is working well. Even though technical analysis suggests that investors might be able to generate excess returns by using trading strategies compared to a buy-and-hold strategy, the differences between conditional and unconditional mean results are weakly significant by majority only and it is doubtful if excess returns can be realized effectively, or if transaction costs, bid-ask spreads, taxes, and other issues dispose or significantly reduce excess returns. Thus, from a practical point of view, there is no final answer to the question of market efficiency in emerging securitized real estate markets.

Since the analysis focuses on weak-form market efficiency only, its results do not contribute to answering the question of whether private and hidden information is more prevalent or less prevalent in the analyzed emerging real estate stock markets than in matured markets. Furthermore, the analysis does not give any information on whether investors are able to 
generate superior performance by using such private information. This question is not the topic of this paper and is left to further research. 


\section{References}

Abraham, A., F.J. Fazal, and S.A. Alsakran (2002): Testing the Random Walk Behavior and Efficiency of the Gulf Stock Markets, Financial Review 37(3), 469-480.

Agbeyegbe, T.D. (1994): Some Stylised Facts about the Jamaica Stock Market, Social and Economic Studies 43(4), 143-156.

Barnes, P. (1986): Thin Trading and Stock Market Efficiency: The Case of the Kuala Lumpur Stock Exchange, Journal of Business Finance and Accounting 13(4), 609-617.

Belaire-Franch, J., S. McGreal, K.K. Opong, and J.R. Webb (2007): A Nonparametric Variance-Ratio Test of the Behavior of U.K. Real Estate and Construction Indices, International Real Estate Review 10(2), 94-112.

Box, G., and D. Pierce (1970): Distribution of Residual Autocorrelations in Autoregressive Integrated Moving Average Time Series Models, Journal of the American Statistical Association 65(332), 1509-1526.

Brock, W., J. Lakonishok, and B. LeBaron (1992): Simple Technical Trading Rules and the Stochastic Properties of Stock Returns, The Journal of Finance 47(5), 1731-1764.

Butler, K.C., and S.J. Malaikah (1992): Efficiency and Inefficiency in Thinly Traded Stock Markets: Kuwait and Saudi Arabia, Journal of Banking and Finance 16(1), 197-210.

Campbell, J.Y., A.W. Lo, and A.C. MacKinlay (1997): The Econometrics of Financial Markets, Princeton.

Chang, K.-P., and K.-S. Ting (2000): A Variance Ratio Test of the Random Walk Hypothesis for Taiwan's Stock Market, Applied Financial Economics 10(5), 525-532.

Chow, K.V., and K.C. Denning (1993): A Simple Multiple Variance Ratio Test, Journal of Econometrics 58(3), 385-401.

Dickey, D.A., and W.A. Fuller (1979): Distribution of the Estimators for Autoregressive Time-Series with a Unit Root, Journal of the American Statistical Association 74(366), 427-431. 
Dickey, D.A., and W.A. Fuller (1981): Likelihood Ratio Statistics for Autoregressive Time Series with a Unit Root, Econometrica 49(4), 1057-1072.

Errunza, V.R., and E. Losq (1985): The Behavior of Stock Prices on LDC Markets, Journal of Banking and Finance 9(4), 561-575.

Fama, E.F. (1965): The Behavior of Stock Market Price, Journal of Business 38(1), 34-105.

Fama, E.F. (1970): Efficient Capital Markets: A Review of Theory and Empirical Work, Journal of Finance 25(2), 383-417.

Fama, E.F. (1991): Efficient Capital Markets: II, Journal of Finance 46(5), 1575-1617.

Fama, E.F., and K.R. French (1988): Permanent and Temporary Components of Stock Market Prices, Journal of Political Economy 96(2), 246-273.

French, K.R., and R. Roll (1986): Stock Return Variances - The Arrival of Information and the Reaction of Traders, Journal of Financial Economics 17(1), 5-26.

Graff, R.A., and M.S. Young (1997): Serial Persistence in Equity REIT Returns, Journal of Real Estate Research 14(3), 183-214.

Grieb, T., and M.G. Reyes (1999): Random Walk Tests for Latin American Equity Indexes and Individual Firms, Journal of Financial Research 22(4), 371-383.

Hahn, G.R., and R.W. Hendrickson (1971): A Table of Percentage Points of the Distribution of Large Absolute Value of k Student t Variates and its Applications, Biometrika 58(2), 323-332.

Huang, B. (1995): Do Asian Stock Market Prices Follow Random Walks? Evidence from the Variance Ratio Test, Applied Financial Economics 5(4), 251-256.

Jarque, C.M., and A.K. Bera (1980): Efficient Tests for Normality, Homoscedasticity and Serial Independence of Regression Residuals, Economic Letters 6(3), 255-259.

Jirasakuldech, B., and J.R. Knight (2005): Efficiency in the Market for REITs: Further Evidence, Journal of Real Estate Portfolio Management 11(2), 123-132. 
Karemera, D., K. Ojah, and J.A. Cole (1999): Random Walks and Market Efficiency Tests: Evidence from Emerging Equity Markets, Review of Quantitative Finance and Accounting 13(2), 171-188.

Kleiman, R.T., J.E. Payne, and A.P. Sahu (2002): Random Walk and Market Efficiency: Evidence from International Real Estate Markets, Journal of Real Estate Research 24(3), 279-297.

Kuhle, J.L., and J.R. Alvayay (2000): The Efficiency of Equity REIT Prices, Journal of Real Estate Portfolio Management 6(4), 349-354.

Laurence, M.M. (1986): Weak Form Efficiency in the Kuala Lumpur and Singapore Stock Markets, Journal of Banking and Finance 10(3), 431-445.

Lim, K.-P., M.S. Habibullah, and M.J. Hinich (2009): The Weak-Form Efficiency of Chinese Stock Markets: Thin Trading, Nonlinearity and Episodic Serial Dependencies, Journal of Emerging Market Finance 8(2), 133-163.

Liu, C.Y., and J. He (1991): A Variance-Ratio Test of Random Walks in Foreign Exchange Rates, Journal of Finance 46(2), 773-785.

Lo, A.W., and A.C. MacKinlay (1988): Stock Market Prices Do Not Follow Random Walks: Evidence from a Simple Specification Test, Review of Financial Studies 1(1), 41-66.

Lo, A.W., and A.C. MacKinlay (1989): The Size and Power of the Variance Ratio Test in Finite Samples, Journal of Econometrics 40(2), 203-238.

Lucas, R.E. (1978): Asset Prices in an Exchange Economy, Econometrica 46(6), 1429-1445.

Mei, J., and B. Gao (1995): Price Reversal, Transaction Costs, and Arbitrage Profits in the Real Estate Securities Market, Journal of Real Estate Finance and Economics 11(2), 153165.

Nelling, E., and J. Gyourko (1998): The Predictability of Equity REIT Returns, Journal of Real Estate Research 16(3), 251-268.

Ojah, K., and D. Karemera (1999): RandomWalk and Market Efficiency Tests of Latin American Emerging Equity Markets: A Revisit, Financial Review 34(2), 57-72. 
Poterba, J., and L. Summers (1988): Mean-Reversion in Stock Prices: Evidence and Implications, Journal of Financial Economics 22(1), 27-59.

Richardson, M., and J.H. Stock (1989): Drawing Inferences from Statistics based on Multiyear Asset Returns, Journal of Financial Economics 15(2), 323-348.

Ryoo, H.-J., and G. Smith (2002): Korean Stock Prices under Price Limits: Variance Ratio Tests of Random Walks, Applied Financial Economics 12(7), 545-553.

Schindler, F., N. Rottke, and R. Fuess (2009): Testing the Predictability and Efficiency of Securitized Real Estate Markets, ZEW Discussion Paper Series, No. 09-054.

Seck, D. (1996): The Substitutability of Real Estate Assets, Real Estate Economics 24(1), 75 95.

Serrano, C., and M. Hoesli (2009): Are Securitized Real Estate Returns more Predictable than Stock Returns?, Journal of Real Estate Finance and Economics, forthcoming.

Smith, G., K. Jefferis, and H.-J. Ryoo (2002): African Stock Markets: Multiple Variance Ratio Tests of Random Walks, Applied Financial Economics 12(7), 475-484.

Stevenson, S. (2002): Momentum Effects and Mean Reversion in Real Estate Securities, Journal of Real Estate Research 23(1/2), 47-64.

Stoline, M.R., and H.K. Ury (1979): Tables of the Studentized Maximum Modulus Distribution and an Application to Multiple Comparisons among Means, Technometrics 21(1), 87-93.

Summers, L. (1986): Does the Stock Market Rationally Reflect Fundamental Values?, Journal of Finance 41(3), 591-600.

Urrutia, J.L. (1995): Tests of Random Walk and Market Efficiency for Latin American Emerging Equity Markets, Journal of Financial Research 43(3), 299-309.

Urzúa, C.M. (1996): On the Correct Omnibus Tests for Normality, Economic Letters 53(3), 247-251. 
Young, M.S., and R.A. Graff (1996): Systematic Behavior in Real Estate Investment Risk: Performance Persistence in NCREIF Returns, Journal of Real Estate Research 12(3), 369-381. 